\title{
nsSEARCANSST \\ PHYSICALA ANI \\ Gut microbiota in exercise trained Toll-like receptor 5 deficient mice inhibits fatty liver and hepatic inflammation
}

Autor(es): $\quad$ Oyanagi, Eri; Uchida, Masataka; Kremenik, Michael J.; Yano, Hiromi

Publicado por: Imprensa da Universidade de Coimbra

URL persistente:

URI:http://hdl.handle.net/10316.2/44156

DOI:

DOI:https://doi.org/10.14195/2182-7087_ex2018_93

Accessed : $\quad$ 26-Apr-2023 10:43:01

A navegação consulta e descarregamento dos títulos inseridos nas Bibliotecas Digitais UC Digitalis, UC Pombalina e UC Impactum, pressupõem a aceitação plena e sem reservas dos Termos e Condições de Uso destas Bibliotecas Digitais, disponíveis em https://digitalis.uc.pt/pt-pt/termos.

Conforme exposto nos referidos Termos e Condições de Uso, o descarregamento de títulos de acesso restrito requer uma licença válida de autorização devendo o utilizador aceder ao(s) documento(s) a partir de um endereço de IP da instituição detentora da supramencionada licença.

Ao utilizador é apenas permitido o descarregamento para uso pessoal, pelo que o emprego do(s) título(s) descarregado(s) para outro fim, designadamente comercial, carece de autorização do respetivo autor ou editor da obra.

Na medida em que todas as obras da UC Digitalis se encontram protegidas pelo Código do Direito de Autor e Direitos Conexos e demais legislação aplicável, toda a cópia, parcial ou total, deste documento, nos casos em que é legalmente admitida, deverá conter ou fazer-se acompanhar por este aviso. 


\section{ANNALS OF RESEARCH IN SPORT AND PHYSICAL ACTIVITY}




\section{GUT MICROBIOTA IN EXERCISE TRAINED TOLL-LIKE RECEPTOR 5 DEFICIENT MICE INHIBITS FATTY LIVER AND HEPATIC INFLAMMATION}

Eri Oyanagi'; Masataka Uchida²; Michael J. Kremenik'; Hiromi Yano

KEYWORDS: FMT, obese mice, fat accumulation

\section{INTRODUCTION}

Metabolic syndrome may prove to be the greatest crisis to global healthcare. Recent studies have shown that the pathogenesis of metabolic syndrome is associated with the dysfunction of the gut microbiota. Germ-free or antibiotics based manipulation of the microbiota in mice has been shown to have effects on adiposity, glucose tolerance and inflammation. In contrast, we showed that exercise induced changes in the gut microbiota and inhibition of metabolic syndrome in metabolic syndrome-prone mice, were lacking Toll-like receptor 5 (TIr5-/-). However, it is unclear whether gut microbiota in exercise trained T/r5-/- mice is able to inhibit metabolic syndrome in obese mice. Although the idea of transplanting gut microbiota into animals is longstanding, it has never been reported that exercise-induced alterations of microbiota composition enhances host phenotypes. In this study, we investigated the effect of the fecal microbiota transplantation (FMT) from exercise-trained TIr5-/- mice on metabolic syndrome in obese mice.

\section{METHODS}

Male 4-week-old C57BL/6 (wild type: WT, n 24) and TIr5-/- (KO5, n 24) donor mice were housed individually in cages with (wheel running: WR, $n=12$ ) or without (control: Ctrl,

\footnotetext{
1 Department of Health and Sports Science, Kawasaki University of Medical Welfare.

2 Faculty of Sport and Health Science, Ritsumeikan University

Email: eri.oyanagi-7@hotmail.co.jp
} 
$\mathrm{n}=12$ ) a running wheel that was accessible 24 hours per day for 20 weeks. After the end of the treatment, the collected cecam was transplanted into the gut of obese recipient mice (male 12-week-old C57BL/6, n 48), who were induced by a high-fat-diet (HFD), once per week for three weeks by stomach sonde.

\section{RESULTS}

HFD-induced obesity and glucose intolerance, which are indicators of the metabolic syndrome, occurred in all of the recipient mice. Namely, the difference among the gut microbiota did not affect the host phenotypes. In the liver, however, fat accumulation and mRNA expression of TNF-alpha were attenuated by FMT from KO5 WR mice. Thus, the part of the host phenotypes, which are attenuations of HFD-induced-hepatic dysfunction, can be transmitted for a period of time to recipient mice via transplantation of their gut microbiota.

\section{CONCLUSION}

In conclusion, our results suggest that FMT from exercise trained Tlr5-/- mice might induce low fat accumulation with low grade inflammation in the livers of obese mice. 